\title{
Prosedur Fuzzy Tahani Menggunakan Fungsi Representatif Kurva Segitiga dan Trapesium
}

\author{
Wise Ahmad Sofia1, Juhari² \\ ${ }^{1}$ Mahasiswa Jurusan Matematika, UIN Maulana Malik Ibrahim Malang \\ 2Dosen Jurusan Matematika, UIN Maulana Malik Ibrahim Malang \\ Email: waiz1piece@gmail.com, juhari@uin-malang.ac.id
}

\begin{abstract}
ABSTRAK
Fuzzy Tahani merupakan salah satu pengembangan aplikasi logika fuzzy. Pada penelitian ini akan menjelaskan prosedur fuzzy Tahani menggunakan fungsi keanggotaan representatif kurva segitiga dan trapesium dengan langkah fuzzifikasi, penentuan domain fuzzy, fungsi dan derajat keanggotaan, penyusunan kriteria, penentuan nilai fire strength, dan penentuan hasil rekomendasi. Metode fuzzy Tahani menggunakan operasi AND sehingga menghasilkan nilai fire strength minimum yang berpengaruh pada hasil rekomendasi. Kemudian variabel penelitian yang digunakan adalah variabel harga, dimensi, berat, kapasitas baterai, dan tampilan layar. Untuk kurva segitiga terdapat 3 himpunan fuzzy yaitu kecil, sedang, dan besar, sedangkan kurva trapesium terdiri dari 4 himpunan fuzzy yaitu kecil, sedang, besar, dan sangat besar. Data yang digunakan dalam penelitian ini adalah data sekunder smartphone, yang bermerek Oppo, Xiaomi, Samsung, Vivo, dan Asus. Dari hasil analisis data smartphone menurut metode Fuzzy Tahani yang digunakan, variabel-variabel tersebut diolah dengan memasukkan rule-rule yang berjumlah 243 untuk kurva segitiga dan 1.024 untuk kurva trapesium dan kemudian diolah menggunakan operasi AND dan diperoleh kesimpulan bahwa kurva segitiga lebih baik daripada kurva trapesium pada perekomendasian pembelian smartphone.
\end{abstract}

Kata kunci: Logika Fuzzy; Fuzzy Tahani; Smartphone

\begin{abstract}
Fuzzy Tahani is one of the developments of fuzzy logic applications. This study will explain the fuzzy Tahani procedure using representative membership functions of triangular and trapezoidal curves with fuzzification steps, determining fuzzy domains, membership functions and degrees, compiling criteria, determining fire strength values, and determining recommendation results. The fuzzy Tahani method uses the AND operation so as to produce a minimum fire strength value that affects the recommendation results. Then the research variables used are price, dimensions, weight, battery capacity, and screen display variables. For the triangular curve there are 3 fuzzy sets, namely small, medium, and large, while the trapezoidal curve consists of 4 fuzzy sets, namely small, medium, large, and very large. The data used in this study is secondary smartphone data, branded Oppo, Xiaomi, Samsung, Vivo, and Asus. From the results of smartphone data analysis according to the Fuzzy Tahani method used, these variables are processed by entering the rules, amounting to 243 for triangular curves and 1,024 for trapezoidal curves and then processed using AND operation and the conclusion is that triangular curves are better than trapezoidal curves. in recommending the purchase of a smartphone.
\end{abstract}

Keywords: Fuzzy Logic; Fuzzy Tahani; Smartphones 


\section{PENDAHULUAN}

Logika fuzzy merupakan suatu logika yang memiliki banyak nilai sehingga diistilahkan kekaburan atau kesamaran fuzzyness antara benar atau salah. Logika fuzzy menunjukkan sejauh mana suatu nilai itu benar dan sejauh mana suatu nilai itu salah [1]. Derajat keanggotaan nol artinya nilai bukan merupakan anggota himpunan dan satu berarti nilai tersebut adalah anggota himpunan. Dalam logika fuzzy terdapat beberapa metode dalam menentukan dan mencari nilai fuzzy, antara lain: mamdani, tsukamoto, sugeno, tahani, dan lainnya. Dalam metode-metode tersebut, terdapat keunggulan serta kelemahan dalam menentukan dan mengolah variabel fuzzy. Khususnya jika metodemetode tersebut digunakan dalam menentukan perekomendasian suatu barang, harga, nilai, dan lain sebagainya, dikarenakan metode seperti mamdani, tsukamoto, dan sugeno tidak menggunakan dan tidak memiliki nilai fire strength untuk hasil akhir. Logika fuzzy mampu memodelkan fungsi-fungsi nonlinier yang sangat kompleks [5]. Dalam penelitian ini, metode yang digunakan adalah fuzzy tahani yang memiliki nilai fire strength untuk hasil akhir sehingga didapatkan hasil rekomendasi terbaik dalam pembelian smartphone. Fuzzy model tahani dideskripsikan sebagai suatu model yang digunakan untuk memproses pencarian data, hanya saja model ini didasarkan pada operasi-operasi dalam teori himpunan fuzzy untuk mendapatkan informasi yang sesuai dengan kriteria pencarian datanya, sehingga fuzzy model tahani sangat tepat digunakan dalam proses pencarian data yang akurat [2]. Basis data fuzzy model Tahani masih tetap menggunakan relasi standar, hanya saja model ini menggunakan teori himpunan fuzzy untuk mendapatkan informasi pada query-nya. Jadi data awal yang diproses adalah data yang memiliki nilai crisp (pasti atau jelas keberadaannya), dan ketika hendak melakukan proses pencarian data yang bersifat samar maka proses tersebut dinamakan fuzzy query melalui fuzzy database model Tahani [4].

Data penelitian diambil dari website resmi kelima merk smartphone, di antaranya website OPPO, XIAOMI Indonesia, SAMSUNG, VIVO, dan ASUS. Sistem Pendukung Keputusan (SPK) digunakan sebagai alat bantu bagi para pengambil keputusan untuk memperluas kapabilitas para pengambil keputusan, namun tidak untuk menggantikan penilaian para pengambil keputusan. SPK ditujukan untuk keputusan-keputusan yang memerlukan penilaian atau untuk keputusan-keputusan yang sama sekali tidak dapat didukung oleh algoritma. SPK meluas dengan cepat, dari sekedar alat pendukung personal menjadi komoditas yang dipakai bersama [3][6].

Tujuan dari penelitian ini adalah menerapkan prosedur fuzzy tahani menggunakan fungsi representatif kurva segitiga dan kurva trapesium, kemudian didapatkan hasil dari kedua kurva tersebut. Setelah itu, ditentukan kurva terbaik antara kedua kurva tersebut untuk memberikan hasil rekomendasi pembelian smartphone.

\section{METODE}

Data yang digunakan dalam penelitian adalah data sekunder diambil dari web resmi 5 merk smartphone, yaitu Xiaomi, OPPO, Vivo, Samsung, dan Asus. Terdapat 86 data dan 5 variabel. Variabel yang digunakan penelitian ini ada 5 variabel yaitu harga, dimensi, berat, kapasitas baterai, dan tampilan layar. Langkah-langkah prosedur fuzzy tahani menggunakan fungsi representatif kurva segitiga dan kurva trapesium sebagai berikut:
a. Melakukan proses fuzzifikasi
b. Menentukan domain fuzzy
c. Menentukan fungsi dan derajat keanggotaan
d. Menyusun kriteria 


\section{e. Menentukan nilai fire strength \\ f. Menentukan hasil rekomendasi}

\section{HASIL DAN PEMBAHASAN}

Pada penelitian ini digunakan lima variabel fuzzy untuk menyatakan hasil rekomendasi terbaik dari kurva segitiga dan kurva tarpesium pada data pembelian smartphone yaitu harga, dimensi, berat, kapasitas baterai, dan tampilan layar. Pada kurva segitiga, variabel harga terbagi ke dalam tiga himpunan fuzzy yaitu murah, normal, dan mahal, pada variabel dimensi, kapasitas baterai, dan tampilan layar terbagi ke dalam tiga himpunan fuzzy yaitu kecil, sedang, dan besar, sedangkan pada variabel berat terbagi menjadi tiga himpunan fuzzy yaitu ringan, sedang, dan berat. Kemudian pada kurva trapesium, variabel harga terbagi ke dalam empat himpunan fuzzy yaitu murah, normal, agak mahal, dan mahal. Pada variabel dimensi, kapasitas baterai, dan tampilan layar terbagi ke dalam empat himpunan fuzzy yaitu kecil, sedang, besar, dan sangat besar. Sedangkan pada variabel berat terbagi ke dalam empat himpunan fuzzy yaitu ringan, sedang, berat, dan sangat berat.

Berikut prosedur fuzzy tahani menggunakan fungsi representatif kurva segitiga sebagai berikut:

\section{A. Fuzzifikasi}

Proses fuzzifikasi pada penelitian ini dilakukan terhadap lima variabel yang ada yaitu harga, dimensi, berat, kapasitas baterai, dan tampila layar.

1) Fuzzifikasi Harga

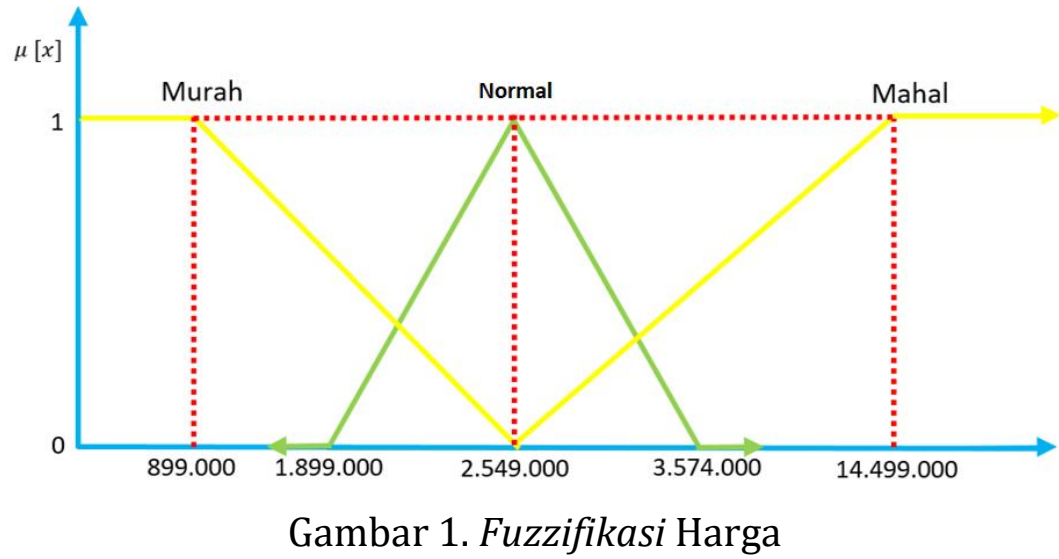

Fungsi Keanggotaan:

$$
\begin{aligned}
& \mu_{\text {harga murah }}[x]=\left\{\begin{aligned}
1, & x \leq 899000 \\
\frac{2549000-x}{2549000-899000}, & 899000<x<2549000 \\
0, & x \geq 2549000
\end{aligned}\right. \\
& \mu_{\text {harga normal }}[x]=\left\{\begin{aligned}
\frac{x-1899000}{2549000-1899000}, & 1899000<x \leq 2549000 \\
\frac{3574000-x}{3574000-2549000}, & 2549000<x<3574000
\end{aligned}\right. \\
& \mu_{\text {harga mahal }}[x]=\left\{\begin{aligned}
\frac{x-2549000}{14499000-2549000}, & 2549000<x<14499000 \\
1, & x \geq 14499000
\end{aligned}\right.
\end{aligned}
$$

2) Fuzzifikasi Dimensi 


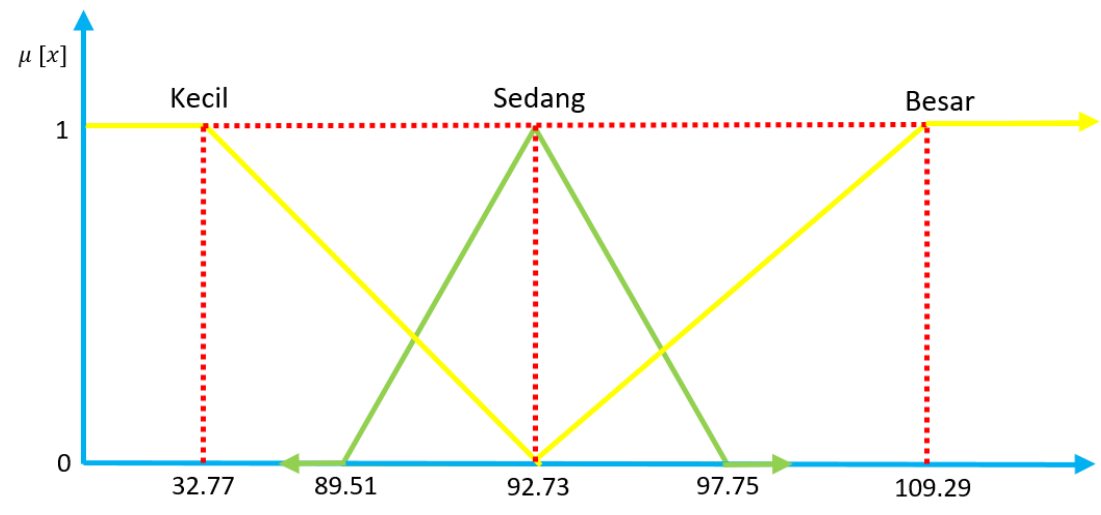

Gambar 2. Fuzzifikasi Dimensi

Fungsi Keanggotaan:

$$
\begin{aligned}
& \mu_{\text {dimensi kecil }}[x]=\left\{\begin{aligned}
1, & x \leq 32.77 \\
\frac{92.73-x}{92.73-32.77}, & 32.77<x<92.73 \\
0, & x \geq 92.73 \\
0, & x \leq 89.51 \text { atau } x \geq 97.75
\end{aligned}\right. \\
& \mu_{\text {dimensi sedang }}[x]=\left\{\begin{aligned}
\frac{x-89.51}{92.73-89.51}, & 89.51<x \leq 92.73 \\
\frac{97.75-x}{97.75-92.73}, & 92.73<x<97.75 \\
0, & x \leq 92.73
\end{aligned}\right. \\
& \mu_{\text {dimensi besar }}[x]=\left\{\begin{aligned}
\frac{x-92.73}{109.29-92.73}, & 92.73<x<109.29 \\
1, & x \geq 109.29
\end{aligned}\right.
\end{aligned}
$$

3) Fuzzifikasi Berat

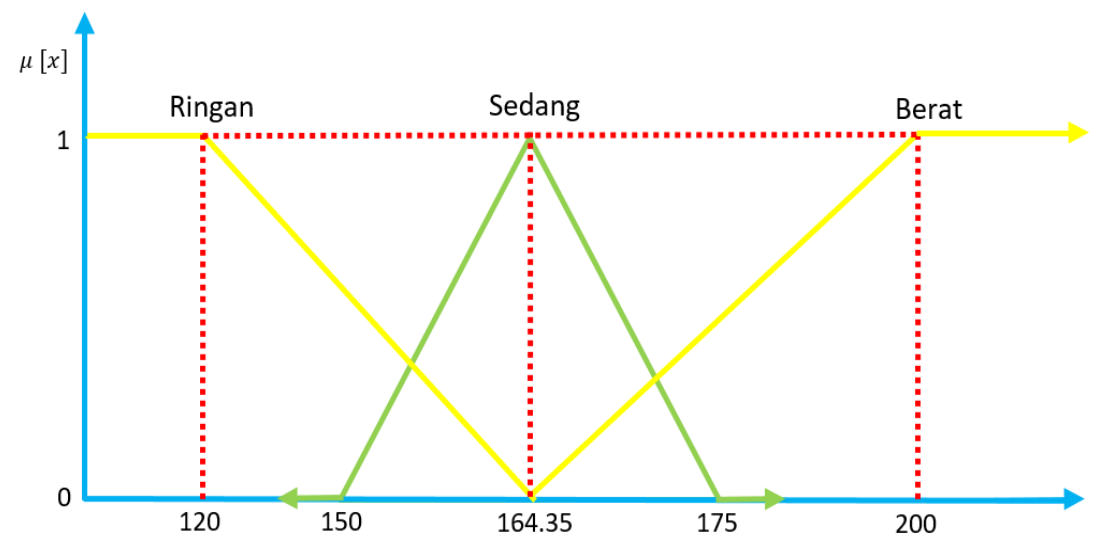

Gambar 3. Fuzzifikasi Berat

Fungsi Keanggotaan:

$$
\begin{aligned}
& \mu_{\text {berat ringan }}[x]=\left\{\begin{aligned}
1, & x \leq 120 \\
\frac{164.35-x}{164.35-120}, & 120<x<164.35 \\
0, & x \geq 164.35
\end{aligned}\right. \\
& \mu_{\text {berat sedang }}[x]=\left\{\begin{aligned}
\frac{x-150}{164.35-150}, & 150<x \leq 164 \text { atau } x \geq 175 \\
\frac{175-x}{175-164.35}, & 164.35<x<175
\end{aligned}\right. \\
& \mu_{\text {berat berat }}[x]=\left\{\begin{aligned}
\frac{x-164.35}{200-164.35}, & 164.35<x<200 \\
1, & x \geq 200
\end{aligned}\right.
\end{aligned}
$$


4) Fuzzifikasi Kapasitas Baterai

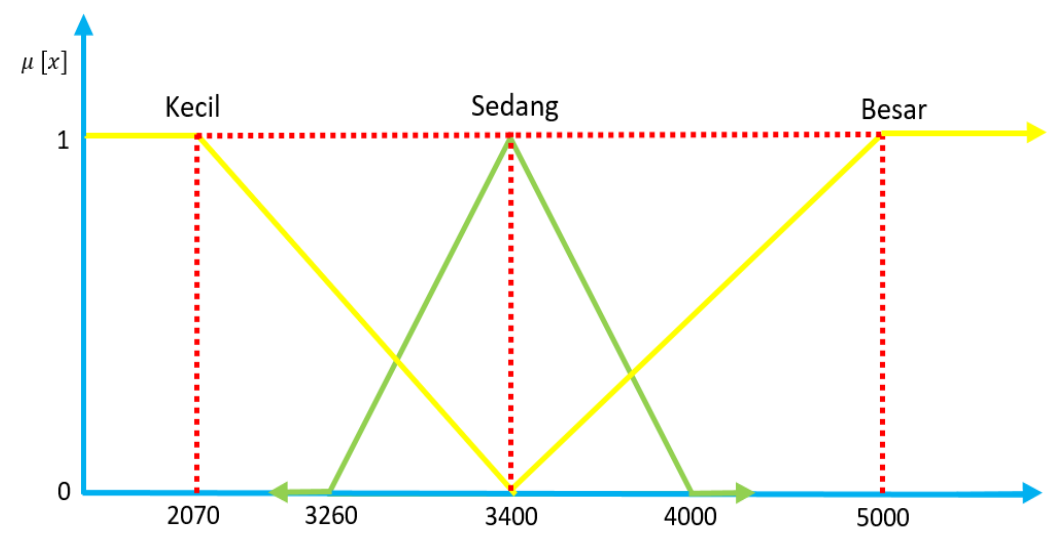

Gambar 4. Fuzzifikasi Kapasitas Baterai

Fungsi Keanggotaan:

$$
\begin{aligned}
& \mu_{\text {kapasitas baterai kecil }}[x]=\left\{\begin{aligned}
1, & x \leq 2070 \\
\frac{3400-x}{3400-2070}, & 2070<x<3400 \\
0, & x \geq 3400
\end{aligned}\right. \\
& \mu_{\text {kapasitas baterai sedang }}[x]=\left\{\begin{aligned}
0, & x \leq 3260 \text { atau } x \geq 4000 \\
\frac{x-3260}{3400-3260}, & 3260<x \leq 3400 \\
\frac{4000-x}{4000-3400}, & 3400<x<4000
\end{aligned}\right. \\
& \mu_{\text {kapasitas baterai besar }}[x]=\left\{\begin{aligned}
0, & x \leq 3400 \\
\frac{x-3400}{5000-3400}, & 3400<x<5000 \\
1, & x \geq 5000
\end{aligned}\right.
\end{aligned}
$$

5) Variabel Tampilan Layar

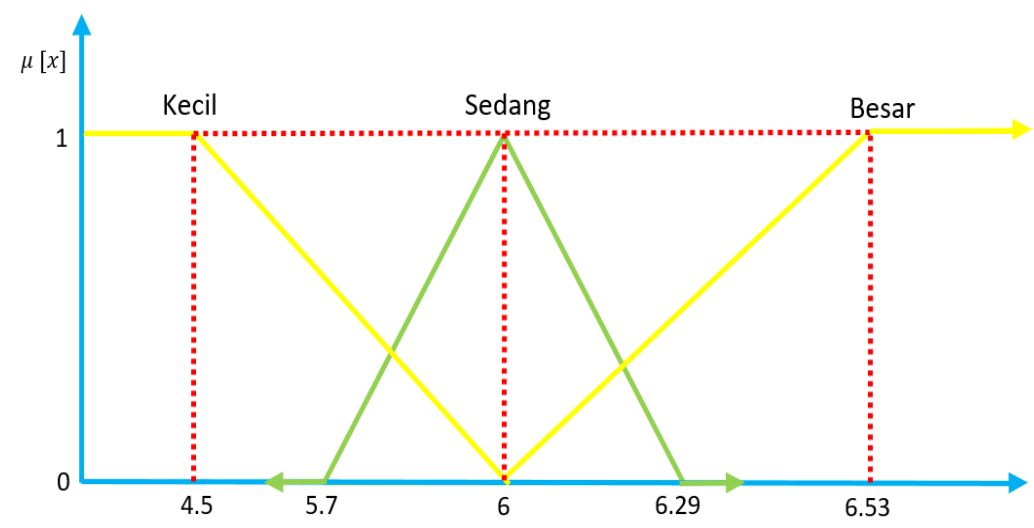

Gambar 5. Fuzzifikasi Tampilan Layar

Fungsi Keanggotaan:

$$
\begin{aligned}
& \mu_{\text {tampilan layar kecil }}[x]=\left\{\begin{array}{rl}
1, & x \leq 4.5 \\
\frac{6-x}{6-4.5}, 4.5<x<6 & 0, x \geq 6
\end{array}\right. \\
& \mu_{\text {tampilan layar sedang }}[x]=\left\{\begin{array}{rr}
0, x \leq 5.7 \text { atau } x \geq 6.29 \\
\frac{x-5.7}{6-5.7}, 5.7<x \leq 6 \\
\frac{6.29-x}{6.29-6}, 6<x<6.29
\end{array}\right.
\end{aligned}
$$




$$
\mu_{\text {tampilan layar besar }}[x]=\left\{\begin{aligned}
0, & x \leq 6 \\
\frac{x-6}{6.53-6}, & 6<x<6.53 \\
1, & x \geq 6.53
\end{aligned}\right.
$$

B. Penyusunan Kriteria

Pada proses penyusunan kriteria, ditentukan beberapa aturan yang akan digunakan untuk menarik kesimpulan. Berikut ini beberapa aturan yang ditentukan pada penelitian ini:

[R1] Harga murah, dimensi kecil, berat ringan, kapasitas baterai kecil, dan tampilan layar kecil

[R81] Harga murah, dimensi besar, berat berat, kapasitas baterai besar, dan tampilan layar besar.

\section{Penentuan Hasil Rekomendasi}

Berdasarkan prosedur fuzzy Tahani menggunakan fungsi keanggotaan kurva segitiga diperoleh kesimpulan bahwa rekomendasi terbaik smartphone pada kriteria 1 adalah merk Asus tipe ZenFone Go dengan harga Rp 899.000,00, dimensi 32,77 $\mathrm{cm}^{3}$, berat 125 gram, kapasitas baterai $2070 \mathrm{mAh}$, dan tampilan layar 4,5 inci. Sedangkan rekomendasi terbaik smartphone pada kriteria 81 adalah merk xiaomi tipe Redmi Note 7 3gb dengan harga Rp 1.999.000,00, dimensi $96,97 \mathrm{~cm}^{3}$, berat 186 gram, kapasitas baterai $4000 \mathrm{mAh}$, dan tampilan layar 6,3 inci.

Berikut prosedur fuzzy tahani menggunakan fungsi representatif kurva trapesium sebagai berikut:

A. Fuzzifikasi

Proses fuzzifikasi pada penelitian ini dilakukan terhadap lima variabel yang ada yaitu harga, dimensi, berat, kapasitas baterai, dan tampilan layar.

1) Fuzzifikasi Harga

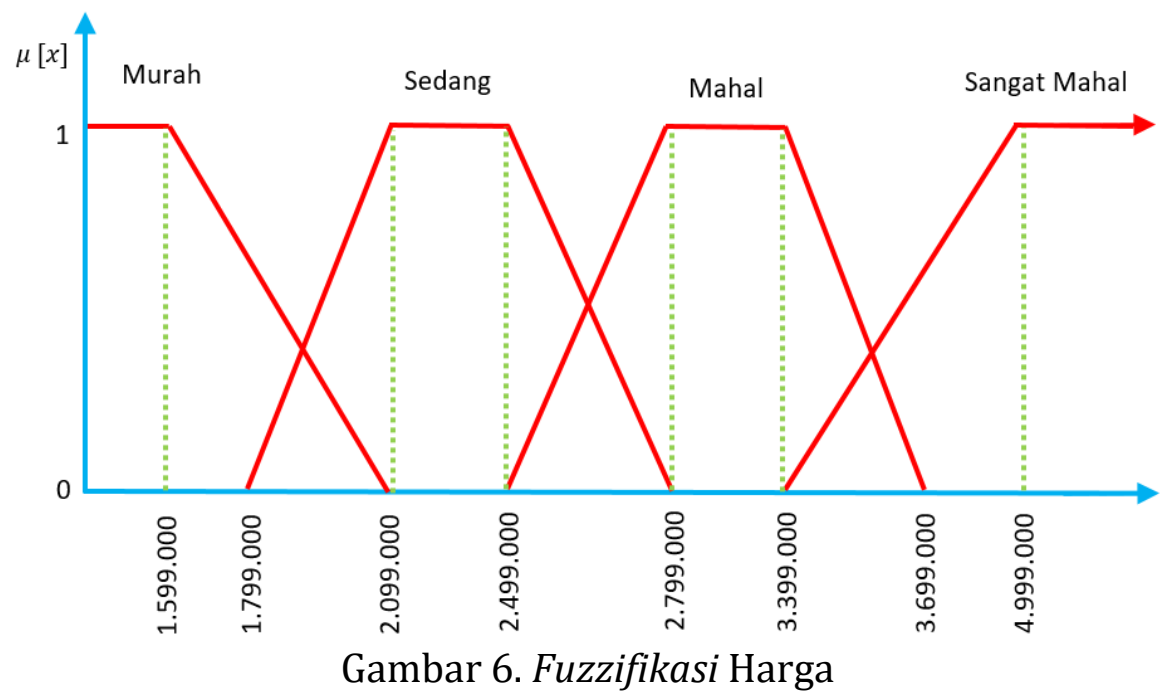


Fungsi Keanggotaan:

$$
\begin{aligned}
& \mu_{\text {harga murah }}[x]=\left\{\begin{aligned}
1, & x \leq 1599000 \\
\frac{2099000-x}{2099000-1599000}, & 1599000<x<2099000 \\
0, & x \geq 2099000
\end{aligned}\right. \\
& \mu_{\text {harga normal }}[x]=\left\{\begin{aligned}
0, & x \leq 1799000 \text { atau } x \geq 2799000 \\
\frac{x-1799000}{2099000-1799000}, & 1799000<x \leq 2099000 \\
1, & 2099000<x \leq 2499000 \\
\frac{2799000-x}{2799000-2499000}, & 2499000<x \leq 2799000
\end{aligned}\right. \\
& \mu_{\text {harga mahal }}[x]=\left\{\begin{aligned}
0, & x \leq 2499000 \text { atau } x \geq 3699000 \\
\frac{x-2499000}{2799000-2499000}, & 2499000<x \leq 2799000 \\
1, & 2799000<x \leq 3399000 \\
\frac{3699000-x}{3699000-3399000}, & 3399000<x \leq 3699000
\end{aligned}\right. \\
& \mu_{\text {harga sangat mahal }}[x]=\left\{\begin{array}{cl}
0, & x \leq 3399000 \\
\frac{x-3399000}{4999000-3399000}, & 3399000<x<4999000 \\
1, & x \geq 4999000
\end{array}\right.
\end{aligned}
$$

2) Fuzzifikasi Dimensi

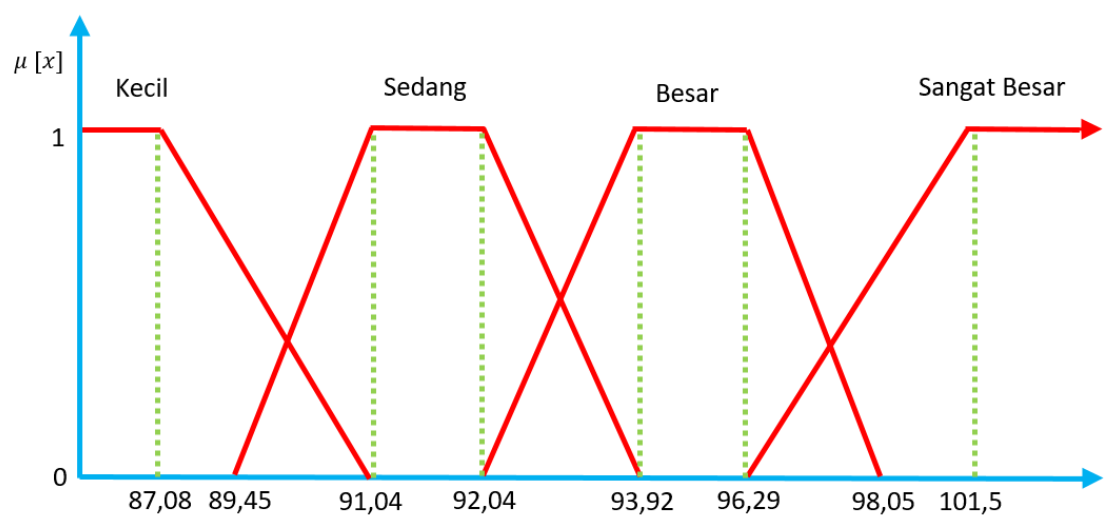

Gambar 7. Fuzzifikasi Dimensi

Fungsi Keanggotaan:

$$
\begin{aligned}
& \mu_{\text {dimensi kecil }}[x]=\left\{\begin{aligned}
1, & x \leq 87,08 \\
\frac{91,16-x}{91,16-87,08}, & 87,08<x<91,16 \\
0, & x \geq 91,16
\end{aligned}\right. \\
& \mu_{\text {dimensi sedang }}[x]=\left\{\begin{aligned}
0, & x \leq 89,45 \text { atau } x \geq 93,92 \\
\frac{x-89,45}{91,16-89,45}, & 89,45<x \leq 91,16 \\
1, & 91,16<x \leq 92,04 \\
\frac{93,92-x}{93,92-92,04}, & 92,04<x \leq 93,92
\end{aligned}\right. \\
& \mu_{\text {dimensi besar }}[x]=\left\{\begin{aligned}
0, & x \leq 92,04 \text { atau } x \geq 98 \\
\frac{x-92,04}{93,92-92,04}, & 92,04<x \leq 93,92 \\
1, & 93,92<x \leq 96,29 \\
\frac{98,05-x}{98,05-96,29}, & 96,29<x \leq 98,05
\end{aligned}\right.
\end{aligned}
$$




$$
\mu_{\text {dimensi sangat besar }}[x]=\left\{\begin{aligned}
0, & x \leq 96,29 \\
\frac{x-96,29}{101,5-96,29}, & 96,29<x<101,5 \\
1, & x \geq 101,5
\end{aligned}\right.
$$

3) Fuzzifikasi Berat

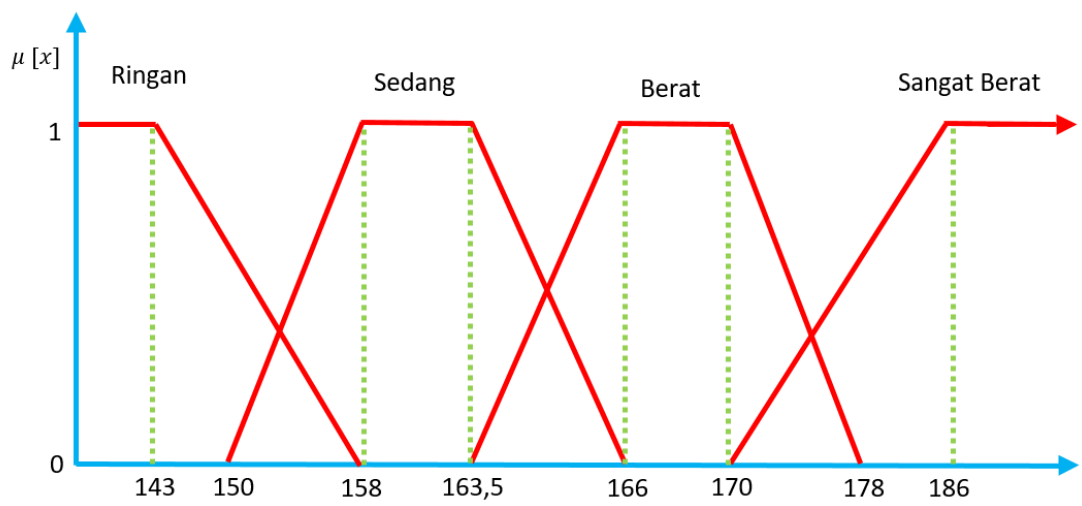

Gambar 8. Fuzzifikasi Berat

Fungsi Keanggotaan:

$$
\begin{aligned}
& \mu_{\text {berat ringan }}[x]=\left\{\begin{aligned}
1, & x \leq 143 \\
\frac{158-x}{158-143}, & 143<x<158 \\
0, & x \geq 158
\end{aligned}\right. \\
& \mu_{\text {berat sedang }}[x]=\left\{\begin{aligned}
0, & x \leq 150 \text { atau } x \geq 166 \\
\frac{x-150}{158-150}, & 150<x \leq 158 \\
1, & 158<x \leq 163,5 \\
\frac{166-x}{166-163,5}, & 163,5<x \leq 166
\end{aligned}\right. \\
& \mu_{\text {berat berat }}[x]=\left\{\begin{aligned}
0, & x \leq 163,5 \text { atau } x \geq 178 \\
\frac{x-163,5}{166-163,5}, & 163,5<x \leq 166 \\
1, & 166<x \leq 170 \\
\frac{178-x}{178-170}, & 170<x \leq 178
\end{aligned}\right. \\
& \mu_{\text {berat sangat berat }}[x]=\left\{\begin{aligned}
0, & x \leq 170 \\
\frac{x-170}{186-170}, & 170<x<186 \\
1, & x \geq 186
\end{aligned}\right.
\end{aligned}
$$

4) Fuzzifikasi Kapasitas Baterai

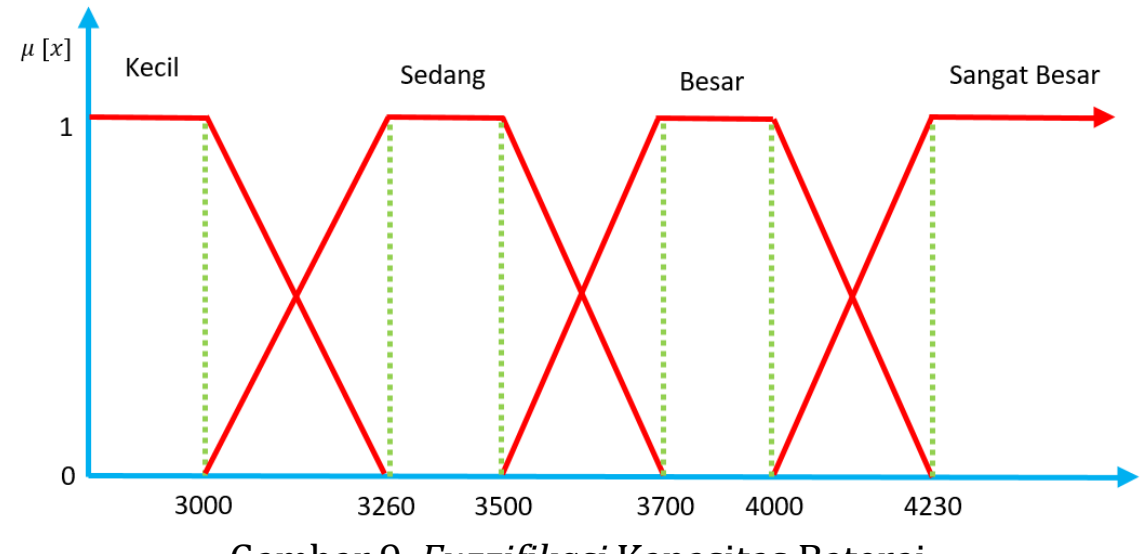

Gambar 9. Fuzzifikasi Kapasitas Baterai 
Fungsi Keanggotaan:

$$
\begin{aligned}
& \mu_{\text {kapasitas baterai kecil }}[x]=\left\{\begin{aligned}
1, & x \leq 3000 \\
\frac{3260-x}{3260-3000}, & 3000<x<3260 \\
0, & x \geq 3260
\end{aligned}\right.
\end{aligned}
$$

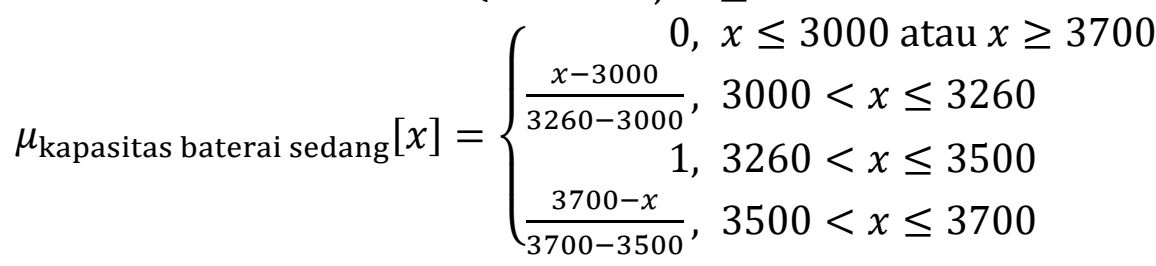

$$
\begin{aligned}
& \mu_{\text {kapasitas baterai besar }}[x]=\left\{\begin{aligned}
0, & x \leq 3500 \text { atau } x \geq 4230 \\
\frac{x-3500}{3700-3500}, & 3500<x \leq 3700 \\
1, & 3700<x \leq 4000 \\
\frac{4230-x}{4230-4000}, & 4000<x \leq 4230
\end{aligned}\right. \\
& \mu_{\text {kapasitas baterai sangat besar }}[x]=\left\{\begin{array}{cl}
0, & x \leq 4000 \\
\frac{x-4000}{4230-4000}, & 4000<x<4230 \\
1, & x \geq 4230
\end{array}\right.
\end{aligned}
$$

5) Fuzzifikasi Tampilan Layar

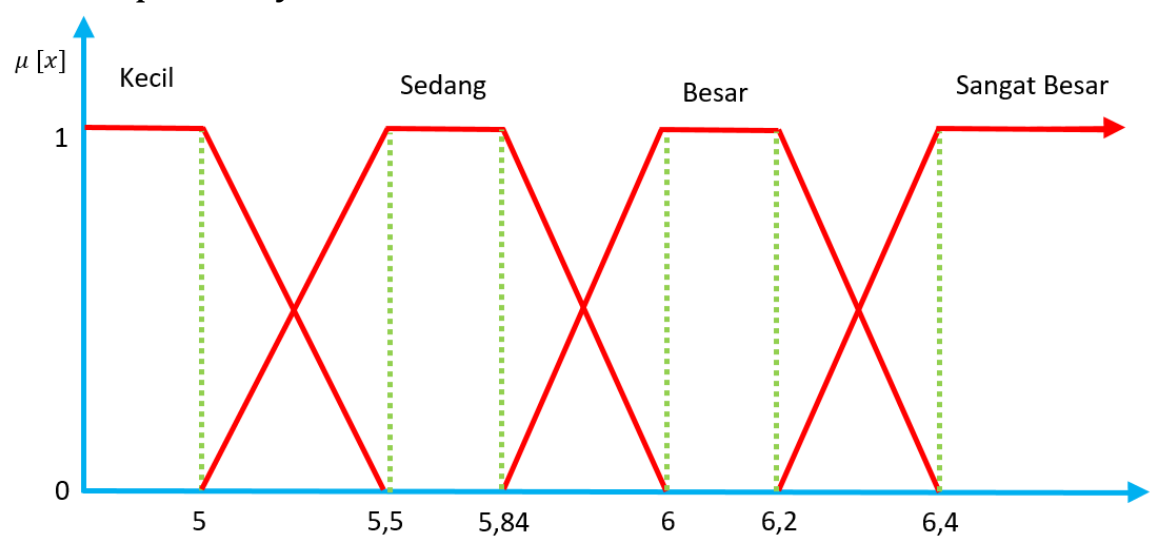

Gambar 10. Fuzzifikasi Tampilan Layar

Fungsi Keanggotaan:

$$
\begin{aligned}
& \mu_{\text {tampilan layar kecil }}[x]=\left\{\begin{aligned}
1, & x \leq 5 \\
\frac{5,5-x}{5,5-5}, & 5<x<5,5 \\
0, & x \geq 5,5
\end{aligned}\right. \\
& \mu_{\text {tampilan layar sedang }}[x]=\left\{\begin{array}{cc}
0, & x \leq 5 \text { atau } x \geq 6 \\
\frac{x-5}{5,5-5}, & 5<x \leq 5,5 \\
1, & 5,5<x \leq 5,84 \\
\frac{6-x}{6-5,84}, & 5,84<x \leq 6
\end{array}\right. \\
& \mu_{\text {tampilan layar besar }}[x]=\left\{\begin{aligned}
0, & x \leq 5,84 \text { atau } x \geq 6,4 \\
\frac{x-5,84}{6-5,84}, & 5,84<x \leq 6 \\
1, & 6<x \leq 6,2 \\
\frac{6,4-x}{6,4-6,2}, & 6,2<x \leq 6,4
\end{aligned}\right.
\end{aligned}
$$




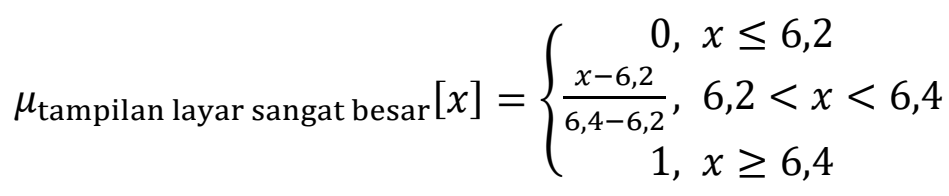

B. Penyusunan Kriteria

Pada proses penyusunan kriteria, ditentukan beberapa aturan yang akan digunakan untuk menarik kesimpulan. Berikut ini beberapa aturan yang ditentukan pada penelitian ini:

[R1] Harga murah, dimensi kecil, berat ringan, kapasitas baterai kecil, dan tampilan layar kecil

[R81] Harga murah, dimensi sedang, berat sedang, kapasitas baterai kecil, dan tampilan layar kecil.

C. Penentuan Hasil Rekomendasi

Berdasarkan prosedur fuzzy Tahani menggunakan fungsi keanggotaan kurva trapesium diperoleh kesimpulan bahwa rekomendasi terbaik smartphone pada kriteria 1 ada 3 pilihan di antaranya: pilihan pertama adalah merk xiaomi tipe Redmi Go dengan harga Rp 899.000,00, dimensi 81,68 cm $\mathrm{cm}^{3}$, berat 137 gram, kapasitas baterai $3000 \mathrm{mAh}$, dan tampilan layar 5 inci. Kemudian pilihan kedua adalah merk Asus tipe ZenFone Go dengan harga Rp 899.000,00, dimensi 32,77 $\mathrm{cm}^{3}$, berat 125 gram, kapasitas baterai $2070 \mathrm{mAh}$, dan tampilan layar 4,5 inci. Pilihan ketiga adalah merk Asus tipe ZenFone Live dengan harga Rp 1.499.000,00, dimensi 79,92 $\mathrm{cm}^{3}$, berat 120 gram, kapasitas baterai $2650 \mathrm{mAh}$, dan tampilan layar 5 inci. Sedangkan pada kriteria 81 tidak terdapat rekomendasi pembelian smartphone.

\section{KESIMPULAN}

Berdasarkan pembahasan di atas, dapat disimpulkan bahwa prosedur fuzzy tahani menggunakan fungsi representatif kurva segitiga dan kurva trapesium pada data pembelian smartphone adalah fuzzifikasi, menentukan domain fuzzy, fungsi dan derajat keanggotaan, menyusun kriteria, menentukan nilai fire strength, dan menentukan hasil rekomendasi. Hasil dari kedua kurva dapat disimpulkan bahwa yang lebih efektif untuk data penelitian ini adalah kurva segitiga dikarenakan memiliki range data yang kecil untuk variabel kapasitas baterai dan tampilan layar sehingga tidak semua kriteria pada kurva trapesium memiliki nilai fire strength. Dengan demikian terdapat beberapa kriteria pada kurva trapesium yang tidak memberikan rekomendasi pembelian smartphone.

\section{REFERENSI}

[1] Yudha D, Made. No. 36 Februari 1997. Sistem Fuzzy: Sebuah Kecenderungan. Science. Hal. 8-9.

[2] Bojadziev G, Bojadziev M,. 2007. Fuzzy Logic for Business, Finance, and Management. Second Edition, Word Scientific, Singapore.

[3] Turban, Efraim, Aroson Jay E., dan Liang, Ting Peng. 2005. Decision Support System and Intelligent System. Edisi Ketujuh.Yogyakarta: Andi. 
[4] Efendi, Rusdi and Rahmi Hidayati. 2014. Aplikasi Fuzzy Database Model Tahani Dalam Memberikan Rekomendasi Pembelian Rumah Berbasis Web. Jurnal Pseudocode 1(1):2355-5920.

[5] Kusumadewi, S. et al. 2006. Fuzzy Multi-Attribute Decision Making (FUZZY MADM). Graha Ilmu. Yogyakarta.

[6] Turban, Efraim, Aroson Jay E., dan Liang, Ting Peng. 2005. Decision Support System and Intelligent System. Edisi Ketujuh.Yogyakarta: Andi. 